\title{
Influence of alternative plant nutrition methods on soil microbial characteristics in long-term experiments
}

\author{
${ }^{1}$ János KÁTAI - ${ }^{2}$ Thomas DÖRING $-{ }^{1}$ Magdolna TÁLLAI $-{ }^{1}$ Andrea BALLA-KovÁCS - \\ ${ }^{3}$ István HENZSEL $-{ }^{3}$ Marianna MAKÁDI $-{ }^{1}$ Zsolt SÁNDOR $-{ }^{1}$ Imre VÁGÓ \\ ${ }^{1}$ Institute of Agricultural Chemistry and Soil Science, Faculty of Agricultural and Food \\ Sciences and Environmental Management, University of Debrecen, Hungary; \\ ${ }^{2}$ Albrecht D. Thaer-Institut für Agrar- und Gartenbauwissenschaften, \\ Lebenswissenschaftliche Fakultät, Humboldt-Universität zu Berlin, Germany; \\ ${ }^{3}$ Research Institute of Nyíregyháza, Institutes for Agricultural Research and Education \\ Farm, University of Debrecen, Hungary
}

\begin{abstract}
The size of the arable land is constantly decreasing all over the world due to severe anthropogenic disorders. Plant production therefore has to be adapted to changing environmental conditions along with the proper selection of crop varieties and the application of sustainable environmental technologies which also consider economic aspects. The investigations were carried out in the Westsik long-term fertilization experiment near Nyíregyháza, East Hungary, which was set up in 1929 (89 years ago). Alternative forms of nutrient supplies (A) (green manure, straw with and without fermentation, organic fertilizer with and without inorganic fertilizer supplements) were used in different crop rotations. The test plant was potato (Solanum tuberosum L.) and the soil type sand with a low humus content (Arenosols). A further long-term experiment is located on calcareous chernozem soil (Chernozems) in Debrecen (set up in 1983, 35 years ago). In one part of this experiment, organic farming (OF) has been carried out with a pea, winter wheat and maize crop rotation for over 15 years with no inorganic fertilization. In another block in this experiment, changes in soil properties as a result of the medium and high doses of fertilizers applied in intensive farming (I) were evaluated with a maize (Zea mays L.) monoculture as the test plant.

The results obtained with alternative nutrient supplies (green manure, fermented and unfermented straw, farmyard manure, fertilization) proved that the soil organic carbon content increased to varying degrees in humus-poor, acidic sand soil. The organic matter content of the soils increased in response to the treatments, contributing to a significant enhancement in soil microbial parameters (MBC, saccharase, dehydrogenase and phosphatase enzyme activities).

The carbon dioxide production and saccharase enzyme activity in organic plots (OF) were significantly lower than in intensively farmed (I) soils. At the same time, in the case of organic farming (OF) the microbial biomass carbon, phosphatase and dehydrogenase activity were significantly higher in OF plots than in I plots.
\end{abstract}

Postal address: JÁNOS KÁTAI, University of Debrecen, Faculty of Agricultural and Food Sciences and Environmental Management, Institute of Agricultural Chemistry and Soil Science, Böszörményi út 138., H-4032 Debrecen, Hungary.

E-mail: katai@agr.unideb.hu 
Compared to the control soil, MBC was 7-8 times higher in organic plots and 1.33.8 times higher in intensive plots.

Organic farming on chernozem soil generally resulted in higher microbial activity (MBC, phosphatase, saccharase and dehydrogenase enzyme activity) than in either intensively farmed chernozem or in the case of alternative farming (A) on sandy soil.

\section{Introduction}

The aim of crop production all over the world is to maintain or increase crop yields in order to produce larger quantities of better quality food and feed raw materials. Crop production has to adapt to changing environmental conditions through the selection of varieties and the application of environmentally sound, economical technologies (LOCH and NosTiCZIUS 2004).

Among the ecological factors, the physical, chemical and biological properties of the soils are of paramount importance, so the complex knowledge of these properties is essential (KÁTAI, 1992). Without this knowledge it is impossible to achieve rational soil use, sustainable soil fertility, and profitable farming (BIRó, 2005)

However, the direction and intensity of the transformation of organic matter depends not only on the soil humus content and the organisms living in the soil, but also on the natural fertility of the soil, the effects of environmental factors and the technology applied. The intensity and speed of humification and mineralization determine the amounts of both organic matter and plant-available minerals in the soil (FÜLEKY and RAJKAINÉ, 1999).

Various organic substances and fertilizers (plant residues, manure, biogas fermentation residues, green manure, compost and slurry) generally have favourable effects on soil biodynamics (MÜLLER, 1991; KÁTAI et al., 1999; KátAI 2000; SZILI-KovÁCS et al., 2009), providing direct nutrient sources for saprotrophic microbes. Other positive effects are caused by humification, better soil structure and improved air and water management.

The effects of fertilizer application on the chemical and microbiological properties of soils have been investigated in many long-term experiments (JANUSAUSKAITE et al., 2013; GeISSELER and SCOW, 2014; KÁtAI et al., 1999, 2014; SZILI-KovÁCS et al., 2009; POWLSON and JohnStON, 1994; SiMON and CZAKO, 2014; ZHAO et al., 2013), which demonstrated that a balanced nutrient supply has a positive effect on the nutrient cycles, energy flow, biodynamics and activity of soil organisms, and thus on the growth and development of plants.

The requirements of organic, integrated and intensive farming vary considerably. Organic farming is based on organic fertilization and biological plant protection, without the use of artificial fertilizer or dangerous plant protection agents (SCHRAMA et al., 2018). The aim of integrated management is to optimize soil fertility and plant nutrition to achieve the desired crop yield (SÁRDI, 2011). The purpose of intensive farming is to achieve the greatest yield. Different plant 
nutrition methods have many direct and/or indirect effects on soil conditions, on nutrient reserves and nutrient content, and on microbiological processes.

The purpose of this study was to compare different forms of nutrient supplies (green manure, livestock manure, inorganic fertilizers and various combinations of these) in organic and conventional farming systems. It was hypothesised that i) organic farming increases soil microbiological biomass and activity compared to conventional farming; ii) there is a close connection between soil nutrient status and microbial biomass and activity, and that this correlation is determined by the farming system; iii) the soil type has a defining role in the intensity of microbial processes. To prove this hypothesis, investigations were made on chemical soil properties and on microbial biomass and activity.

\section{Materials and methods}

\section{Experimental area}

Experiment I.

One part of the investigations was carried out in a long-term fertilization experiment, set up in 1929 by Vilmos Westsik near Nyíregyháza, in the eastern part of Hungary. In this experiment various forms of nutrient supply (green manure, fermented or non-fermented straw, animal manure) were used with or without inorganic fertilizers in different crop rotations on sand with low humus content (WRB: Arenosols) and acidic $\mathrm{pH}$. The test plant was potato. Six of the 15 treatments were selected for the present experiment:

I. AC: control, fallow, without cultivation or fertilization

II. AGM-N: with main-crop lupine as green manure, combined with $\mathrm{N}$ fertilizer

IV. AS-NPK: with fermented straw and NPK fertilizer

VII. AS: with straw but no inorganic fertilizers

XI. AF-N: with farmyard manure and $\mathrm{N}$ fertilizer

XIV. AGM-PK: with second-crop lupine as green manure, ploughed in soil, in autumn, and PK fertilizer

\section{Experiment II.}

In another long-term fertilization experiment, set up in 1983 on a highly fertile calcareous chernozem soil (WRB: Chernozems) in the Hajdúság loess area west of Debrecen in East Hungary, organic farming has been carried out in one block for more than 15 years, with no inorganic fertilizer and a constant maize-wheat-pea crop rotation. The other block involved intensive farm management with medium and high doses of fertilizer. The test crop here was a maize monoculture.

Treatments:

1. Control (C) (maize, without fertilization)

Organic farming (OF)

2. OF, $\mathrm{P}$ (pea)

3. OF, M (maize)

Intensive farm management (using solid $\mathrm{NH}_{4} \mathrm{NO}_{3}, \mathrm{NH}_{4} \mathrm{H}_{2} \mathrm{PO}_{4}$ and $\mathrm{KCl}$ fertilizers) 
4. Medium dose of fertilizers (IMF1): $120,90,90 \mathrm{~kg} \mathrm{ha}^{-1} \mathrm{~N}, \mathrm{P}_{2} \mathrm{O}_{5}, \mathrm{~K}_{2} \mathrm{O}$, resp.

5. Large dose of fertilizers (IMF2): $240,180,180 \mathrm{~kg} \mathrm{ha}^{-1} \mathrm{~N}, \mathrm{P}_{2} \mathrm{O}_{5}, \mathrm{~K}_{2} \mathrm{O}$, resp.

Soil samples were taken from 5 points/treatments at a depth of $2-20 \mathrm{~cm}$ on 10 May 2016.

\section{Chemical and biological soil properties investigated}

Laboratory analyses on moisture content $\left(105^{\circ} \mathrm{C}\right), \mathrm{pH}$ (BUZÁs, 1988), organic carbon content (OC) (SZÉKELY et al., 1960), soil respiration $\left(\mathrm{CO}_{2}\right.$ production) (ÖHLINGER, 1996), microbial biomass carbon (MBC) (VANCE et al, 1987), dehydrogenase activity (MERSHI, 1996), phosphatase activity (SZEGI, 1979) and saccharase activity (FRANKENBERGER and JOHANSON, 1983) were carried out in four replications.

Table 1

Effect of alternative management (A) on some physical and chemical parameters of humiferous sandy soil (Arenosol) (Nyíregyháza, May 2016); test plant: potato

\begin{tabular}{|l|c|c|c|c|c|}
\hline \multicolumn{1}{|c|}{$\begin{array}{c}\text { Treatment } \\
\text { code }\end{array}$} & $\begin{array}{c}\text { Moisture } \\
\text { content \% }\end{array}$ & $\begin{array}{c}\mathrm{pH} \text { in } \\
\text { distilled } \\
\text { water }\end{array}$ & $\begin{array}{c}\mathrm{pH} \text { in } \\
1.0 \mathrm{M} \mathrm{KCl} \\
\text { solution }\end{array}$ & $\begin{array}{c}\text { Humus } \\
\text { content } \\
\%\end{array}$ & $\begin{array}{c}\text { Organic C } \\
\text { content } \mathrm{kg}^{-1}\end{array}$ \\
\hline I. Control AC & 5.49 & 5.40 & 3.88 & $0.51 \mathrm{a}$ & $3.0 \mathrm{a}$ \\
\hline II. AGM-N & 5.97 & 4.76 & 3.51 & $0.54 \mathrm{a}$ & $3.1 \mathrm{a}$ \\
\hline IV. AS-NPK & 5.66 & 4.37 & 3.51 & $0.62 \mathrm{ab}$ & $3.6 \mathrm{ab}$ \\
\hline VII. AS & 6.58 & 6.24 & 4.93 & $0.64 \mathrm{ab}$ & $3.7 \mathrm{ab}$ \\
\hline XI. AF-N & 5.64 & 5.37 & 4.44 & $0.83 \mathrm{c}$ & $4.8 \mathrm{c}$ \\
\hline XIV. AGM-PK & 7.58 & 5.18 & 3.74 & $0.83 \mathrm{c}$ & $4.8 \mathrm{c}$ \\
\hline LSD & - & - & - & 0.09 & 0.5 \\
\hline
\end{tabular}

For treatment details, see Materials and methods

\section{Statistical analyses}

One-way ANOVA was used for determining treatment effects and the standard deviation (S.D.) of the means was calculated using the SPSS 13.0 program at the $5.0 \%$ significance level. After ANOVA, Duncan's multiple range test was used to compare the means. Values indicated with different letters were significantly different from each other at the $5.0 \%$ significance level. Pearson correlation analysis was used to reveal correlations between microbiological and chemical soil properties.

\section{Results and discussion}

\section{Westsik research experiment (Experiment I)}

The soils in the Westsik experiment in Nyíregyháza had very low moisture content at the sampling date (Table 1). Based on the $\mathrm{pH}$ values, the soils could be classified as acidic, with the exception of the AS-F treatment, which was only slightly acidic. The soils also had low or very low organic carbon content, which rose slightly compared to the control in response to green manure (AGM-N), straw 
(AS) and straw + nitrogen fertilizer (AS-N), and increased significantly in the AF-N and AGM-PK treatments.

The carbon dioxide production of the soils increased slightly in all the treatments (Table 2), but only showed a significant increase in the AF-N treatment. Microbial biomass carbon (MBC) significantly increased in all the treatments, with particularly high values in the green manure treatments (AGM-N, AGM-PK). The humiferous sandy soil had very low saccharase enzyme activity in the control plot, but the values were more than doubled by the straw (AS-NPK) and green manure plus PK fertilizer (AGM-PK) treatments. The highest phosphatase activity was found in the green manure - mineral fertilizer (AGM-PK) combination, followed by the farmyard manure plus mineral $\mathrm{N}$ fertilizer (AF-N) treatment. All treatments with the exception of unfermented straw (AS-NPK) resulted in significant increases (1.1 to 1.8 fold). Similarly high activity was measured for dehydrogenase in the AGM-PK and AF-N treatments, but except for the AGM-N treatment, a significant increase was observed in all the treatments compared with the control.

Table 2

Effect of alternative management on some soil microbial characteristics of humiferous sand (Arenosols) (Nyíregyháza, May 2016)

\begin{tabular}{|l|c|c|c|c|c|}
\hline \multicolumn{1}{|c|}{ Treatment } & $\begin{array}{c}\mathrm{CO}_{2} \\
\mathrm{mg} / 100 \mathrm{~g} \\
\text { soil/10 days }\end{array}$ & $\begin{array}{c}\mathrm{MBC} \\
\mu \mathrm{g} \mathrm{g}^{-1}\end{array}$ & $\begin{array}{c}\text { Saccharase } \\
\text { glycose } \mathrm{mg}\end{array}$ & $\begin{array}{c}\text { Phosphatase } \\
\mathrm{mg}^{100 \mathrm{~g}^{-1}} \\
2 \mathrm{~h}^{-1}\end{array}$ & $\begin{array}{c}\text { Dehydroge } \\
\text { nase INTF } \\
\mu \mathrm{g} 100 \mathrm{~g}^{-1}\end{array}$ \\
\hline I. Control AC & $8.65 \mathrm{a}$ & $134.21 \mathrm{a}$ & $2.12 \mathrm{a}$ & $11.23 \mathrm{a}$ & $35.13 \mathrm{a}$ \\
\hline II. AGM-N & $8.89 \mathrm{a}$ & $251.14 \mathrm{~b}$ & $2.52 \mathrm{a}$ & $15.37 \mathrm{~b}$ & $37.73 \mathrm{a}$ \\
\hline IV. AS-NPK & $8.90 \mathrm{a}$ & $192.89 \mathrm{c}$ & $4.76 \mathrm{~b}$ & $12.21 \mathrm{a}$ & $39.80 \mathrm{~b}$ \\
\hline VII. AS & $8.87 \mathrm{a}$ & $226.56 \mathrm{~d}$ & $3.97 \mathrm{c}$ & $15.93 \mathrm{~b}$ & $40.15 \mathrm{~b}$ \\
\hline XI. AF-N & $9.59 \mathrm{~b}$ & $163.17 \mathrm{e}$ & $3.86 \mathrm{c}$ & $17.13 \mathrm{~b}$ & $47.43 \mathrm{c}$ \\
\hline XIV. AGM-PK & $8.85 \mathrm{a}$ & $256.62 \mathrm{~b}$ & $4.97 \mathrm{~b}$ & $20.22 \mathrm{c}$ & $48.40 \mathrm{c}$ \\
\hline LSD $_{5 \%}$ & 0.62 & 23.94 & 0.62 & 1.29 & 3.65 \\
\hline
\end{tabular}

For treatment details, see Materials and methods

INTF = reduced iodonitrotetrazolium formazan

\section{Debrecen-Látókép experimental site (Experiment II.)}

The soils in the Debrecen-Látókép experiment had higher than average moisture content at the time of sampling (Table 3). The soil $\mathrm{pH}_{\left(\mathrm{H}_{2} \mathrm{O}\right)}$ ranged from 5.93 to 6.27 , and could be classified as slightly acidic. Compared to the untreated control, the soils of both organic (OF) and intensive farming (I) were more acidic. Compared with the control, the fertilizer treatments (IMF1, IMF2) used in intensive farming (I) caused a significant increase in the organic carbon content. On the organic plots (OF) the soil organic carbon content was lower than in the intensive plots, but did not differ significantly from the control. 
Table 3

Effect of organic farming (OF) and intensive management (I) on some physical and chemical parameters of calcareous chernozem soil (Chernozems) (Debrecen-Látókép, May 2016)

\begin{tabular}{|c|c|c|c|c|c|c|}
\hline Treatment & Crop & $\begin{array}{c}\text { Moisture } \\
\text { content } \\
\%\end{array}$ & $\begin{array}{c}\mathrm{pH} \text { in } \\
\text { distilled } \\
\text { water }\end{array}$ & $\begin{array}{c}\mathrm{pH} \text { in } 1.0 \\
\mathrm{M} \mathrm{KCl} \\
\text { solution }\end{array}$ & $\begin{array}{c}\text { Humus } \\
\text { content } \\
\%\end{array}$ & $\begin{array}{c}\text { Organic C } \\
\text { content } \mathrm{g} \\
\mathrm{kg}^{-1}\end{array}$ \\
\hline a. Control MC & Maize & 19.30 & 6.27 & 5.09 & $2.76 \mathrm{a}$ & $16.0 \mathrm{a}$ \\
\hline \multicolumn{7}{|l|}{ Organic farming } \\
\hline b. OF Pea & Pea & 20.56 & 5.99 & 4.88 & $2.62 \mathrm{a}$ & $15.2 \mathrm{a}$ \\
\hline c. OF Maize & Maize & 22.43 & 5.93 & 5.12 & $2.75 \mathrm{a}$ & $15.9 \mathrm{a}$ \\
\hline \multicolumn{7}{|l|}{ Intensive farming } \\
\hline $\begin{array}{l}\text { d. Medium dose } \\
\text { IMF1 }\end{array}$ & Maize & 19.19 & 6.04 & 4.85 & $3.03 \mathrm{a}$ & $17.4 \mathrm{~b}$ \\
\hline $\begin{array}{l}\text { e. Large dose } \\
\text { IMF2 }\end{array}$ & Maize & 19.15 & 5.95 & 4.71 & $3.17 \mathrm{ab}$ & $18.2 b$ \\
\hline$L S D_{5 \%}$ & & - & - & - & 0.31 & 0.82 \\
\hline
\end{tabular}

For treatment details, see Materials and methods

Table 4

Effect of organic farming (OF) and intensive management (I) on some microbial parameters of calcareous chernozem soil (Chernozems) (Debrecen-Látókép, May 2016)

\begin{tabular}{|c|c|c|c|c|c|}
\hline Treatment & $\begin{array}{c}\mathrm{CO}_{2} \mathrm{mg} \\
100 \mathrm{~g} \mathrm{soil}^{-1} \\
10 \text { days }^{-1}\end{array}$ & $\begin{array}{l}\mathrm{MBC} \\
\mu \mathrm{g} \mathrm{g}^{-1}\end{array}$ & $\begin{array}{c}\text { Saccharase } \\
\text { glycose mg } \\
100 \mathrm{~g}^{-1}\end{array}$ & $\begin{array}{c}\text { Phosphatase } \\
\text { mg } \\
100 \mathrm{~g}^{-1} 2 \mathrm{~h}^{-1}\end{array}$ & 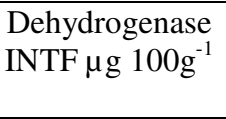 \\
\hline a. Control MC & $19.53 \mathrm{a}$ & $36.95 \mathrm{a}$ & $14.43 \mathrm{a}$ & $12.75 \mathrm{a}$ & $25.90 \mathrm{a}$ \\
\hline \multicolumn{6}{|l|}{ Organic farming } \\
\hline b. OF Pea & $10.71 b$ & $245.50 \mathrm{~b}$ & $10.55 b$ & $20.47 b$ & $50.58 b$ \\
\hline c. OF Maize & $10.76 \mathrm{~b}$ & $275.55 b$ & $9.39 \mathrm{~b}$ & $21.44 \mathrm{~b}$ & $53.10 \mathrm{~b}$ \\
\hline \multicolumn{6}{|c|}{ Intensive farming } \\
\hline $\begin{array}{l}\text { d. Medium } \\
\text { dose IMF1 }\end{array}$ & $19.88 \mathrm{a}$ & $51.37 \mathrm{a}$ & $13.13 \mathrm{a}$ & $13.67 \mathrm{a}$ & $33.20 \mathrm{c}$ \\
\hline $\begin{array}{l}\text { e. Larger dose } \\
\text { IMF2 }\end{array}$ & $19.98 \mathrm{a}$ & $143.33 c$ & $13.16 \mathrm{a}$ & $15.52 \mathrm{a}$ & $33.75 \mathrm{c}$ \\
\hline$L S D_{5 \%}$ & 1.07 & 34.30 & 1.65 & 3.85 & 3.85 \\
\hline
\end{tabular}

$\mathrm{INTF}=$ reduced iodonitrotetrazolium formazan

The carbon dioxide production and saccharase enzyme activity of the soil were significantly lower in the case of organic farming (OF) than for intensive farming (I) (Table 4). At the same time, the microbial biomass carbon, phosphatase and dehydrogenase activity were significantly higher on organic (OF) than on intensive plots (I). The highest phosphatase and dehydrogenase activity was measured in the organically farmed soils. Compared to the control soil, $M B C$ was 7-8 times higher in the case of organic farm management (OF) and 1.3-3.8 times higher for intensive farming (I). Inorganic fertilizers (IMF1, IMF2) significantly increased the MBC values in the soil. 
In intensive farming (I), the carbon dioxide production, saccharase and phosphatase enzyme activity were similar to the control values. Mineral fertilization (IMF1, IMF2) resulted in higher values for both enzymes compared to the control, but this increase was only slight for phosphatase. The dehydrogenase enzyme activity showed a significant increase in these treatments.

\section{Table 5}

Pearson's correlations between soil properties Management system A (Nyíregyháza): $n=24$; Management systems OF and I (Debrecen-Látókép): $n=20$

\begin{tabular}{|c|c|c|c|c|c|c|c|c|}
\hline $\begin{array}{c}\text { Measured } \\
\text { parameters }\end{array}$ & $\begin{array}{c}\text { Manage- } \\
\text { ment } \\
\text { system }\end{array}$ & $\begin{array}{l}\text { Mois- } \\
\text { ture } \\
\text { content }\end{array}$ & $\begin{array}{l}\mathrm{pH} \\
\text { (H2O) }\end{array}$ & $\begin{array}{l}\text { Orga- } \\
\text { nic } \\
\text { car- } \\
\text { bon }\end{array}$ & $\begin{array}{l}\mathrm{CO}_{2} \\
\text { produc- } \\
\text { tion }\end{array}$ & $\mathrm{MBC}$ & $\begin{array}{l}\text { S-ase } \\
\text { acti }\end{array}$ & $\begin{array}{l}\text { P-ase } \\
\text { ity }\end{array}$ \\
\hline $\begin{array}{l}\text { a. Moisture } \\
\text { content }\end{array}$ & $\begin{array}{c}\text { A } \\
\text { OF, I }\end{array}$ & & & & & & & \\
\hline b. $\mathrm{pH}_{(\mathrm{H} 2 \mathrm{O})}$ & $\begin{array}{c}\text { A } \\
\text { OF, I }\end{array}$ & -- & & & & & & \\
\hline $\begin{array}{l}\text { c. Organic } \\
\text { carbon }\end{array}$ & $\begin{array}{c}\text { A } \\
\text { OF, I }\end{array}$ & - & - & & & & & \\
\hline $\begin{array}{l}\text { d. } \mathrm{CO}_{2} \\
\text { production }\end{array}$ & $\begin{array}{c}\text { A } \\
\text { OF, I }\end{array}$ & $\begin{array}{l}- \\
-\end{array}$ & $\begin{array}{l}- \\
-\end{array}$ & $\begin{array}{c}- \\
0.775\end{array}$ & & & & \\
\hline e. $\mathrm{MBC}$ & $\begin{array}{c}\text { A } \\
\text { OF, I }\end{array}$ & $\begin{array}{l}0.666 \\
0.698\end{array}$ & $\begin{array}{c}- \\
0.699\end{array}$ & - & $\begin{array}{c}- \\
-0.885\end{array}$ & & & \\
\hline $\begin{array}{l}\text { f. Saccharase } \\
\text { activity }\end{array}$ & $\begin{array}{c}\text { A } \\
\text { OF, I }\end{array}$ & $\begin{array}{c}- \\
-0.751\end{array}$ & $\begin{array}{c}- \\
0.572\end{array}$ & $\begin{array}{c}0.603 \\
-\end{array}$ & $\begin{array}{c}- \\
0.830\end{array}$ & -0.822 & & \\
\hline $\begin{array}{l}\text { g. } \\
\text { Phosphatase } \\
\text { activity }\end{array}$ & $\begin{array}{c}\mathrm{A} \\
\mathrm{OF}, \mathrm{I}\end{array}$ & $\begin{array}{l}0.684 \\
0.591\end{array}$ & $\begin{array}{c}- \\
-0.58\end{array}$ & 0.728 & $\begin{array}{c}- \\
-0.824\end{array}$ & $\begin{array}{l}0.615 \\
0.843\end{array}$ & $\begin{array}{c}- \\
0.757\end{array}$ & \\
\hline $\begin{array}{l}\text { h. } \\
\text { Dehydrogenas } \\
\text { e activity }\end{array}$ & $\begin{array}{c}\text { A } \\
\text { OF, I }\end{array}$ & $\begin{array}{c}- \\
0.635\end{array}$ & $\begin{array}{c}- \\
0.713\end{array}$ & $\begin{array}{c}0.871 \\
-\end{array}$ & $\begin{array}{c}- \\
-0.874\end{array}$ & $\begin{array}{c}- \\
0.885\end{array}$ & $\begin{array}{c}0.620 \\
- \\
0.830\end{array}$ & $\begin{array}{l}0.757 \\
0.832\end{array}$ \\
\hline
\end{tabular}

All he given correlations are significant at the 0.01 level (2-tailed).

Management systems: organic (OF), intensive (I) and alternative (A) farming

$\mathrm{MBC}=$ microbial biomass carbon, $\mathrm{S}$-ase $=$ saccharase, $\mathrm{P}$-ase $=$ phosphatase 
Correlations between physico-chemical and biological parameters

Pearson's correlations were calculated to reveal correlations between the chemical and biological properties of the soil (Table 5), and the correlations found between microbial biomass carbon and phosphatase enzyme activity, and between phosphatase and saccharase enzyme activity are depicted in Figures 1 and 2, respectively, from which it can be seen that these pairs of parameters were in close connection with each other.

Studies in the Westsik long-term experiment (KÁTAI et al., 1999) showed that the use of white lupine straw or green manure supplemented with NPK enhanced the nitrate, AL-soluble phosphorus and potassium contents of the soil. The addition of straw, green manure or livestock manure had a stimulating effect on the activity of the saccharase and phosphatase enzymes to varying degrees.

Among the microbiological properties of the soil, the value of MBC and the activitiy of the saccharase, urease and dehydrogenase enzymes were significantly increased by alternative nutrient supplies (green manure, farmyard manure and straw) in the acidic, humus-poor sandy soil tested in the Westsik experiment. These results were consistent with previous results (KÁTAI et al., 2002).

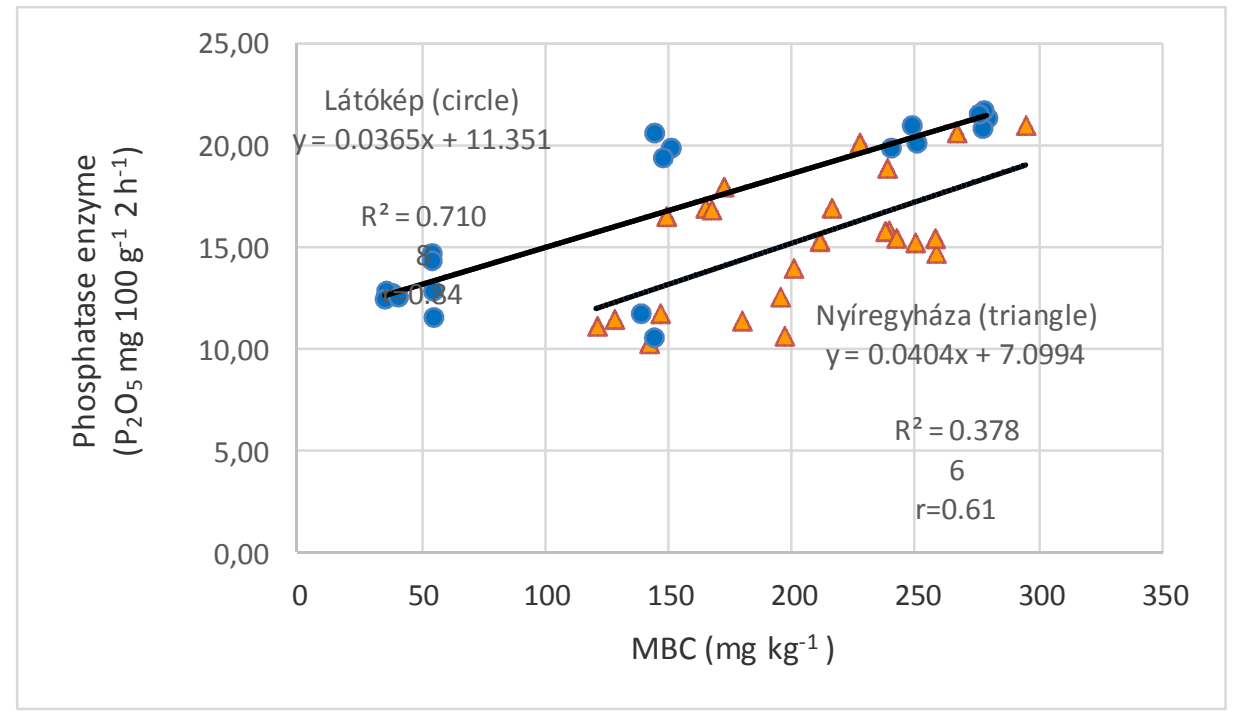

Figure 1

Correlation between MBC and phosphatase enzyme activity (Pearson's correlations, Nyíregyháza n=24; Debrecen - Látókép n=20) 


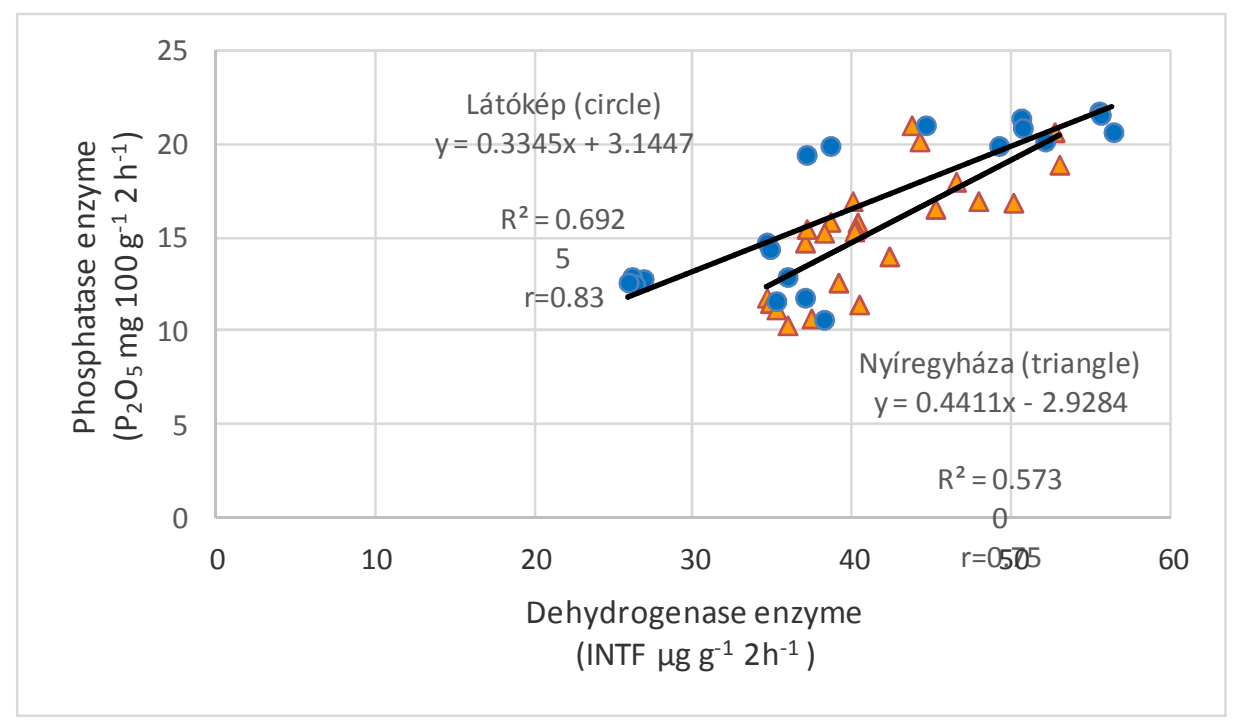

Figure 2

Correlation between the dehydrogenase and phosphatase enzyme activities (Pearson's correlations, Nyíregyháza n=24; Debrecen - Látókép n=20)

PIOTROWSKA-DLUGOSZ and WILCZEWSKI (2015) found a similar phenomenon: green harvestings (catch crop, pea, Pisum sativum L.) increased MBC and the activity of soil enzymes, including saccharase, so these authors recommended greening for the stimulation of microbial activity. A similar conclusion was drawn by BOLTON et al. (1985) and LOSAKOV et al. (1986).

\section{Comparison between organic and intensive farming conditions}

When assessing the effects of organic and intensive farming on soil microbiological processes, the values of $\mathrm{MBC}$, phosphatase and dehydrogenase activity were found to be higher in organic farming than in intensive farming, while higher carbon dioxide production and saccharase activity were measured in intensive farming.

Organic manure plus inorganic fertilizer increased the microbial biomass carbon by 74-99\% (LiU et al., 2013). STEVLIKOVA et al. (2002) also demonstrated that $\mathrm{MBC}$ values were higher in organic than in intensive farming.

LUKÁCSNÉ and ZSUPOSNÉ (2008) reported higher values of phosphatase and dehydrogenase activity, $\mathrm{MBC}$ and $\mathrm{CO}_{2}$ production in organic farming than in traditional farming systems. As in the present work, the saccharase enzyme activity proved to be higher in the traditional farming system.

BALEZENTIENE and KLIMAS (2009) found that nitrogen application stimulated the activity of saccharase, but the lowest values were measured with inorganic fertilization, suggesting that saccharase (and urease) activity is a bioactive property, usually positively correlated with soil nutrient content. In their view, the activity of 
the two enzymes is a bio-indicator of soil fertility, responding well to the type of manure used and the system of nutrition management.

In summary, it can be concluded that straw, green manure and farmyard manure had a potent effect on the soil microbiological characteristics studied. Organic farming also contributed significantly to the increased activation of soil microbiological processes.

\section{Conclusions}

As a result of alternative nutrient supplies (A), the soil organic carbon content increased in all the treatments compared to the control. This increase was significant in the AF-M (inorganic fertilizer plus farmyard manure) and AGM-F (green manure plus inorganic fertilizer) treatments. The higher organic matter contents resulting from the treatments contributed to the significant enhancement of soil microbial parameters (MBC, saccharase, dehydrogenase and phosphatase enzyme activities).

The organic (OF) and intensive (I) cultivation treatments in the long-term experiment on calcareous chernozem soil (Debrecen-Látókép) had shorter life periods, only existing since 2000 and 1983, respectively.

Comparing the organic and intensive farming systems, it can be concluded that the carbon dioxide production and saccharase activity of organic plots (OF) were significantly lower than on intensive plots (I). In contrast, the microbial biomass carbon and the phosphatase and dehydrogenase activity were significantly higher in organic farm management systems (OF) than in the intensive farming system (I). These results are in harmony with data from the literature and also highlighted the need for sustainable production technologies.

\section{Acknowledgements}

This research was financially subsidised by "EKHAGA Stiftelsen", Stockholm, Sweden. Project title: "Healthy plants from healthy soils: Resilience and stability of organic cropping systems". Project number: 2015-65.

\section{References}

Balezentiene, L., Klimas, E. 2009. Effect of organic and mineral fertilizers and land management on soil enzyme activities. Agronomy Research 7. (Special issue I) 191-197.p.

BIRÓ, B. 2005. The soil as a living substance. In: The importance and value of soils in the 21st century. (eds. STEFAnOvits P. \& MichÉLI E.). (In Hungarian) MTA, Budapest. p. 141-169.

Bolton, H., ElLIOTT, L. F, PAPENDICK, R. I., BEZDiceK, D. F. 1985. Soil microbial biomass and selected soil enzyme activities: effect of fertilization and cropping practices. Soil Biology and Biochemistry. 17. (3) 297-302. p. 
BuZÁs, I. (ed.) 1988. Methods of Soil and Agricultural Chemistry Analysis 2. Physico-chemical and Chemical Methods of Soil Analysis. (In Hungarian) Mezőgazdasági Kiadó, Budapest. pp. 90-93.

FÜlEKY, G., RAJKAINÉ VÉGH, K. 1999. Nutrient supplying ability of the soil. (ed. G. FÜLEKY). In: soil-nutrient-management. (In Hungarian) Mezőgazdasági Kiadó, Budapest. p. 112-120.

FrANKERBERGER, W.T., JOHANSON, J.B. 1983. Method of measuring invertase activity in soils. Plant and Soil. 74. 301-311.

GEISSELER, D., SCOW, K.M. 2014. Long-term effects of mineral fertilizers on soil microorganisms. A review. Soil Biology and Biochemistry. 75. 54-63.

Janusauskaite, D., Arlauskiene, A., Maikteniene, S. 2013. Soil mineral nitrogen and microbial parameters as influenced by catch crops and straw management. Zemdirbyste Agriculture, 100 (1) 9-18.

KÁtAI, J. 1992. Correlation among the physical, chemical characteristics and microbiological activities of some soil types. In: Functioning and Dynamics of Perturbed Ecosystems. eds. Bellan, D., Bonin, G., EMIG, C. Lavoisier Publishing, Paris. p. 137-158.

KÁTAI, J., LAZÁNYI, J., VERES, E. 1999. Investigation of soil microbiological parameters in Westsik long-term field experiment. In: Tiszántúli Mezőgazdasági Tudományos Napok. (In Hungarian). Debrecen, 1999. okt. 2829. p. 175-184.

KÁTAI, J. 2000. Comparative investigations on soil microbiological parameters in a long-term fertilizer experiment. For the $80^{\text {th }}$ anniversary of the birth of Prof. Ernő Bocz. (In Hungarian). Debrecen. p. 51-63.

KÁtai, J., Zsuposné OlÁH, Á., SÁNDOR, Z., TÁllai, M. 2014. Comparison of soil parameters of the carbon and nitrogen cycles in a long-term fertilization field experiment. Agrokémia és Talajtan. 63. 129-138.

LIU, E., YAN, C., MEI, X., ZHANG, Y. FAN, T. 2013. Long-term effect of manure and fertilizer on soil organic carbon pools in dryland farming in Northwest China. PlosOne. https://doi.org/10.1371/journal.pone.0056536

LoCH, J., NosticziUs, Á. 2004. Agro-chemistry and Plant Protection Chemistry. Mezőgazda Kiadó, Budapest. 19-22, 114.

Losakov, V. G., Emcev, V.T., Nicé, L. K., Ivanova, Sz. F., Rogova, T. A. 1986. Biologicseszkaja aktivnoszt pocsvy $\mathrm{v}$ szpecinivnogo sziderata i szolomy $\mathrm{v}$ kacsesztve udobrenij. Izv. TSZHA. Moszkva 4. pp. 10-17.

LUKÁCSNÉ VERES E. - ZSUPOSNÉ OLÁH Á. 2008. Mészlepedékes csernozjom talaj fontosabb paramétereinek alakulása hagyományos és ökológiai gazdálkodási rendszerekben. Talajvédelem különszáma (ed.: SIMON L.) 455-464. p.

MüLlER, G. 1991. Soil microbiological aspects of agroecology and intensive agricultural production. (In Hungarian) Agrokémia és Talajtan. 40. 263-272.

MERSHI, V. W. 1996. Dehydrogenase activity with the substrate INT. In: Schinner, F., ÖHLINGER, R., KAndeler, E., MARgesin, R. (eds.) Methods in Soil Biology. Springer-Verlag Berlin - Heidelberg. 243-245. 
ÖHLINGer, R., KANDEler, E., MARgesin, R. (eds.) 1996. Methods in Soil Biology. Springer-Verlag Berlin Heidelberg. pp. 20-26., 32-36

PIOTROWSKA-DLUGOSZ, A., WILCZEWSKI, E. 2015. Influences of catch crop and its corporation time on soil carbon and carbon-related enzymes. Pedosphere. 25. (4) 569-579. p.

POWLSON, D. S., Johnston, A. E. 1994. Long-term Field Experiments: their Importance in Understanding Sustainable Land Use. Soil Resilience and Sustainable Land Use. CAB International. 367-394.p.

SÁRDI, K. 2011. Soil-nutrient management. Debreceni Egyetem, NyugatMagyarországi Egyetem, Pannon Egyetem (on-line teaching material). (In Hungarian).

Schrama, M., De HaAn, J.J., Kroonen, M, Verstegen, H., VAn Der Putten, W. H. 2018. Crop yield gap and stability in organic and conventional farming systems. Agriculture, Ecosystems and Environment. 256. 123-130.

SIMON, T., CZAKO, A. 2014. Influence of long-term application of organic and inorganic fertilizers on soil properties. Plant Soil and Environment. 60. 314319.

STEVlívKovÁ, T., JAVOREKOVÁ, S., VJATRÁKOVÁ, J. 2002. Soil biological activity within integrated and ecological management of soil. Agrártudományi Közlemények 1. Acta Agraria Debreceniensis. Debrecen. 47-52. p.

SZÉKELY, Á., SCHLICK, B., SZABÓ, T. 1960. On the photometric and colorimetric determination of organic carbon. (In Hungarian). Agrokémia és Talajtan, 9. 111-120.

SZEGI, J. 1979. Soil Microbiological Methods. (In Hungarian) Mezőgazda Kiadó, Budapest. pp. 250-256.

SZILI-KovÁCS, T., ZsuPOSNÉ OlÁH, Á., KÁTAI, J., VILláNYI, I., TAKÁCS, T. 2009. Correlation between biological and chemical properties in soils from long-term experiments. Agrokémia és Talajtan (In Hungarian). 58. 309-325.

VANCE, E.D., BROOKES, P.C., JENKINSON, D.S. 1987. An extraction method for measuring soil microbial biomass-C. Soil Biol. Biochem. 19. 703-707.

ZhaO, B., Chen, J., Zhang, J., XIN, X., HaO, X. 2013. How different long-term fertilization strategies influence crop yield and soil properties in a maize field in the North China Plain. Journal of Plant Nutrition and Soil Science. 176. 99109. 